\title{
UPAYA MENINGKATKAN PRESTASI BELAJAR MATEMATIKA DENGAN METODE PROBLEM-BASED LEARNING PADA POKOK BAHASAN LOGIKA MATEMATIKA DI KELAS X-1SMA NEGERI 2 SUMENEP TAHUN PELAJARAN 2010-2011
}

\author{
Hasanudin \\ Guru SMAN 2 Sumenep
}

\begin{abstract}
ABSTRAK
Untuk meningkatkan prestasi belajar siswa khususnya mata pelajaran matematika perlu dicarikan upaya-upaya yang tepat dan efektif serta efisien. Salah satu upayanya adalah pemilihan strategi pembelajaran yang dapat diterapkan dalam pembelajaran matematika. Salah satunya adalah Problem-Based Learning. Dalam pembelajaran matematika, khususnya dalam penyelesaian soal-soal logika dibanding dengan beberapa keunggulan, diantaranya siswa lebih aktif untuk berdiskusi dan berkolaborasi dalam menyelesaikan masalah. Penelitian ini bertujuan untuk: (1) mengetahui kemampuan siswa dalam menyelesaikan soal-soal pada pokok bahaasan Logika matematika. (2) mengetahui prestasi belajar siswa pada pokok bahasan Logika Matematika. (3) mengetahui dampak metode Problem-Based Learrning dalam meningkatkan prestasi belajar siswa pada pokok bahasan Logika Matematika. Dengan metode Problem Based Learning dapat meningkatkan kemampuan siswa dalam menyelesaikan soal-soal latihan pokok bahasan logika Matematika di kelas X-I UPT SMA Negeri 2 Sumenep Tahun Pelajaran 2010-2011; Hal ini dapat dilihat dari perolehan nilai rata-rata ulangan harian yang semua sebelum diadakan penelitian 42,8 dengan ketuntasan 43\% pada siklus I 69,3 dengan ketuntasan 69\% dan pada siklus II 74,3 dengan ketuntasan $74 \%$.
\end{abstract}

\section{Kata kunci : Prestasi belajar, Logika, Problem-Based learning}

\section{PENDAHULUAN}

Dalam pembelajaran matematika banyak guru yang mengeluhkan rendahnya kemampuan siswa dalam menerapkan konsep matematika. Hal ini terlihat dari banyaknya kesalahan siswa dalam memahami konsep matematika sehingga mengakibatkan rendahnya prestasai belajar siswa (skor) baik dalam ulangan harian, ulangan semester, maupun ujian akhir sekolah, padahal dalam pelaksanaan proses pembelajaran di kelas biasanya guru memberikan tugas (pemantapan) secara kontinu berupa latihan soal.

Belajar pada prinsipnya adalah proses perubahan tingkah laku sebagai akibat dari interaksi antara siswa dengan sumber-sumber atau obyek belajar baik secara sengaja dirancang (Suliana, 2005). Proses belajar siswa tersebut menghasilkan perilaku yang dikehendaki, suatu hasil belajar sebagai dampak pengajaran (Dimyati \& Mudjiono, 2002)
"Prestasi belajar adalah suatu nilai yang menunjukkan hasil tertinggi dalam belajar yang diacapai menurut kemampuan anak dalam mengerjakan sesuatu pada saat tertentu pula". (Sumartono, 1971), sedangkan Belajar dengan pendekatan yang menggunakan masalah dunia nyata sebagai suatu konteks bagi siswa belajar tentang cara berpikir kritis dan keterampilan pemecahan, serta untuk memperoleh pengetahuan dan konsep yang esensi dari materi pelajaran. (Nurhadi, Burhan \& Agus, 2004).

Para ahli penelitian telah menemukan teori-teori dan prinsip-prinsip belajar. Diantara prinsip-prinsip belajar yang penting berkenaan dengan :

1) Perhatian dan motivasi belajar siswa

2) Keaktifan belajar

3) Keterlibatan dalam belajar

4) Pengulangan belajar

5) Tantangan semangat belajar

6) Pemberian balikan dan penguatan belajar 
7) Adanya perbedaan individual dalam perilaku belajar

Berdasarkan latar belakang tersebut, rumusan masalah dalam penelitian ini adalah sebagai berikut:

1) Apakah dengan metode ProblemBased Learning dapat meningkatkan kemampuan siswa dalam mengerjakan soal-soal latihan pada pokok bahasan Logika Matematika di Kelas X-1 UPT SMA Negeri 2 Sumenep tahun pelajaran 2010-2011?

2) Apakah dengan metode ProblemBased Lerning dapat meningkatkan prestasi belajar siswa kelas pada pokok bahasan Logika Matematika di kelas X-1 UPT SMA Negeri 2 Sumenep tahun Pelajaran 20102011 ?

3) Bagaimanakah dampak metode Problem-Based Learning dalam meningkatkan prestasi belajar siswa pada materi Logika Matematika siswa kelas X-1 UPT SMA Negeri 2 Sumenep Tahun Pelajaran 20102011 ?

Penelitian ini menggunakan pembelajaran berbasis masalah (ProblemBased Learning). Pembelajaran berbasis masalah (Problem-Based Learning) adalah suatu pendekatan pembelajaran yang menggunakan masalah dunia nyata sebagai suatu konteks bagi siswa untuk belajar cara berpikir kritis dan keterampilan masalah, serta untuk mem-peroleh pengetahuan dan pemahaman konsep yang esensial dari materi pelajaran agar dalam Pembelajaran mendapatkan peningkatan dalam berpikir kritis dan keterampilan masalah.

\section{METODE PENELITIAN}

\section{Jenis Penelitian}

Untuk mencapai tujuan tersebut penelitian perlu dicarikan jalan yang tepat, efisien dan sistematis. Cara dan teknik yang digunakan dalam penelitian dapat memberi, mencari, mengumpulkan dan menganalisis data cara inilahyang disebut metode penelitian. Adapun jenis penelitian ini adalah Penelitian Tindakan Kelas (PTK).

Penelitian tindakan kelas (PTK) ini dilakukan dalam dua siklus. Adapun tahapan-tahapan dalam pelaksanaan penelitian tindakan kelas (PTK) digambarkan dalam skema (dalam Hayat 2007:26). Penelitian tindakan kelas dilaksanakan di kelas X-1 SMAN 2 Sumenep Semester Genap tahun pelajaran 2010-2011 dengan pokok bahasan Logika Matematika yang berjumlah 40 siswa.

Langkah-langkah yang ditempuh dalam penelitian ini adalah:

\section{Siklus I}

a. Perencanaan (Planning)

Dalam tahap perencanaan Peneliti bersama kolaborator mempersiapkan: Silabus, soal-soal ulangan harian, instrumen penelitian, materi pelajaran yaitu Logika Matematika.

b. Pelaksanaan (Acting)

Peneliti membimbing siswa dalam menyelesaikan soal Logika Matematika dengan pendekatan Problem-Based Learning membentuk suatu diskusi kelompok kecil. Peneliti memberi kesempatan kepada siswa untuk bertanya, sementara kolaborator mengamati proses pembelajaran sebagai bahan diskusi selanjutnya.

c. Pengamatan (Observing)

Kolaborator melakukan pengamatan terhadap kegiatan siswa, baik tentang sikap maupun tingkah laku selama kegiatan pembelajaran.

d. Refleksi (Reflecting)

Dalam tahap ini merupakan kegiatan menganalisa, mensintesa dari hasil pengamatan selama proses pembelajaran pada siklus I berlangsung dan diadakan ulangan harian yang digunakan untuk mengetahui hasil belajar baik secara individu maupun klasikal.

e. Perbaikan dan Pengayaan

Apabila dalam pelaksanaan pembelajaran kurang hasilnya kurang 
memuaskan maka dicari penyebab dan penyelesaian untuk mengatasi permasalahan yang dihadapi, perlu adanya perbaikan dengan mengadakan ulangan remedial dan pengayaan bagi siswa yang telah mendapat standart ketuntasan minimal.

\section{Siklus II}

Pada siklus II merupakan tindak lanjut dari siklus I dengan memperhatikan hasil observasi, diskusi dengan kolaborator serta hasil belajar siswa juga mengetahui ketuntasan belajar siswa secara individu maupun klasikal, maka Peneliti bersama kolaborator merencanakan proses pembelajaran selanjutnya. Adapun langkah-langkah pada siklus II adalah sebagai berikut :

a. Perencanaan

Menyiapkan silabus, menyiapkan soal-soal evaluasi II Instrumen penelitian, Materi Pelajaran yaitu Logika Matematika.

b. Pelaksanaan Tindakan

Pada siklus II pelaksanaan pembelajaran perlu dimodifikasi sedikit, ini diharapkan akan lebih memberi motivasi dan semangat siswa dalam belajar.

c. Pengamatan (observasi)

Ketika siswa melakukan kegiatan belajar pada siklus II, Kolaborator mengamati perubahan sikap dengan memberikan instrumen (angket) yang harus diisi oleh siswa untuk diamati pembelajaran yang telah dilaksanakan dengan memperlihatkan hasil nilai ulangan II.

d. Refleksi

Dalam tahap ini perlu menganalisa, mensintesa dari hasil proses pembelajaran pada siklus II berlangsung, dan diadakan ulangan harian yang digunakan untuk mengetahui hasil belajar baik secara individu maupun klasikal.

e. Perbaikan

Jika hasil pembelajaran kurang sesuai dengan harapan, baik secara klasikal maupun individu, maka dicari penyebab permasalahan yang dihadapi, kemudian dilakukan remedial dan pengayaan, bagi siswa yang telah mencapai standar ketuntasan minimal dan jika belum berhasil maka penelitian kembali ke siklus ke II dan selanjutnya.

\section{Instrumen Penelitian}

Untuk mencapai maksud tersebut diatas, peneliti dalam hal ini menggunakan metode pengumpulan data, yaitu :

1. Metode Test

Metode tes adalah suatu metode yang digunakan untuk mengetahui pengetahuan yang dimiliki seseorang dengan menggunakan soal-soal isian dengan batasan tertentu.

Tes digunakan untuk mengukur keterampilan, pengetahuan intelegensi kemampuan atau bakat yang dimiliki oleh individu atau kelompok dan sebagainya yang telah dipilih dengan sempurna dan standart tertentu.

Metode tes yang digunakan pada ini adalah ulangan harian yang dilakukan pada akhir siklus guna memperoleh data yang diinginkan.

2. Metode Angket

Metode angket adalah suatu metode pengumpulan data dengan jalan mengajukan suatu daftar pertanyaan tertulis kepada sejumlah individu dan individu yang diberi daftar pertanyaan tersebut diminta untuk memberikan jawaban secara tertulis pula. Pada penelitian ini digunakan sejumlah angket langsung dan tertutup. Dikatakan angket langsung, karena individu yang diberi angket tersebut adalah orang yang diinginkan langsung datanya yaitu siswa.

3. Metode Observasi

Berdasarkan pengertian psikologi, observasi atau yang disebut dengan pengamatan, meliputi kegiatan pemusatan perhatian terhadap obyek dengan mengunakan seluruh alat indra. Jadi mengobservasi adalah pengamatan langsung melalui penglihatan, penciuman, pendengaran, peraba dan pengecap. 
Teknik observasi yang dilakukan dalam penelitian ini adalah observasi dengan menggunakan format yang sudah disiapkan sehingga kolaborator pada lembar observasi. Tinggal memberi tanda ( $\sqrt{ })$ (check list).

\section{Teknik Analisa Data}

Teknik analisa data merupakan unsur yang sangat penting dalam setiap kali melakukan penelitian. Semua data yang telah terkumpul tidak akan berarti kalau tidak diadakan penganalisaan. Hasil dari penganalisaan akan memberikan gambaran, arah serta tujuan dan maksud penelitian.

Penelitian ini menggunakan analisa statistik sederhana, yaitu dengan analisa diskriptif. Analisa diskriptif adalah model analisa dengan cara membandingkan ratarata prosentasenya, kemudian kenaikan rata-rata pada setiap siklus. Disini yang dianalisa yaitu tentang hasil ulangan pada tiap siklus.

Dari hasil ulangan tersebut, dapat ditafsirkan tentang ketuntasan belajar siswa. Dalam penelitian ini untuk ketuntasan belajar siswa individu maupun klasikal digunakan pedoman ketuntasan siswa, sebagai berikut :

1. Ketuntasan Perorangan

Seorang siswa dikatakan tuntas bila telah mencapai taraf penguasaan minimal $60 \%$ atau dengan nilai 60 . Bagi siswa penguasaannya kurang dari $60 \%$ diberikan remidi pada pokok bahasan yang belum dikuasai, sedangkan bagi siswa yang penguasaan $60 \%$ atau lebih dapat melanjutkan kepokok bahasan berikutnya.

2. Ketuntasan Klasikal

Suatu kelas dikatakan tuntas jika paling sedikit $85 \%$ data jumlah siswa dalam kelas tersebut telah mencapai ketuntasan perorangan dengan ketentuan sebagai berikut :

a) Apabila sudah terdapat $85 \%$ siswa dalam satu kelas telah mencapai tingkat ketuntasan belajar maka kelas tersebut dapat melanjutkan kegiatan pada satuan pembelajaran berikutnya.

b) Apabila Siswa dalam kelas masih kurang dari $85 \%$ maka :

1) Siswa yang taraf penguasaan-nya kurang dari $60 \%$ harus diberi program perbaikan mengenai bagian-bagian pelajaran yang belum dikuasai.

2) Siswa yang telah mencapai taraf penguasaan $60 \%$ atau lebih dapat diberikan program pengayaan.

Untuk menentukan prosentase dari pencapaian ketuntasan siswa maupun kelas adalah sebagai berikut:

$$
\begin{aligned}
& \% \text { Ketuntasan Siswa }=\text { Sp } \times 100 \% \\
& \% \text { Ketuntasan Kelas }=\text { St } \times 100 \%
\end{aligned}
$$

Keterangan :

$\mathrm{sp}=$ skor perolehan

st $=$ skor total

$\mathrm{s}=\sum$ jumlah siswa yang mencapai ketuntasan

$\mathrm{t}=$ jumlah siswa total dalam kelas

jika dalam suatu kelas tuntas lebih dari $85 \%$ maka pembelajaran dapat dikatakan berhasil. Tetapi jika ketuntasan siswa kurang dari $85 \%$ maka pembelajaran yang dianggap belum berhasil dan perlu diperhatikan mengenai metode dalam pembelajaran.

\section{HASIL DANPEMBAHASAN Hasil Temuan}

Agar dalam penelitian ini peneliti mendapatkan hasil yang sesuai dengan harapan maka peneliti menggunakan metode siklus. Adapun pelaksanaan dari siklus-siklus tersebut adalah sebagai berikut:

\section{Siklus I}

1. Perencanaan tindakan I

a. Guru melaksanakan kegiatan pembelajaran sesuai yang direncanakan dengan kolaborator dengan bentuk klasikal. 
b. Siswa duduk berkelompok sesuai dengan tempat duduk yang berdekatan dalam satu garis bangku dengan anggota 4-5 orang.

c. Guru memberikan tugas secara berkelompok dan individu.

d. Guru mengamati proses berlangsungnya belajar kelompok.

e. Kolaborator membuat catatan pribadi (catatan lapangan).

f. Guru memberikan tes pada siswa.

\section{Pelaksanaan Tindakan I}

Siklus I ini merupakan tahap awal dari penelitian yaitu dengan mengambil data ulangan harian siswa yang terkahir sebelum diadakan penelitian, hal ini digunakan sebagai pembanding. Data ulangan harian dengan pokok bahasan Logika Matematika di kelas X-I yang terakhir adalah sebagai berikut:

Tabel 1. Hasil Nilai Ulangan Harian Pra PTK

\begin{tabular}{cccc}
\hline No & Nilai & Frekuensi & Prosentase \\
\hline 1 & 20 & 6 & $15 \%$ \\
\hline 2 & 30 & 8 & $20 \%$ \\
\hline 3 & 40 & 9 & $22 \%$ \\
\hline 4 & 50 & 9 & $23 \%$ \\
\hline 5 & 60 & 2 & $5 \%$ \\
\hline 6 & 70 & 6 & $15 \%$ \\
\hline Jumlah & 40 & $100 \%$ \\
\hline Jumlah Total Nilai & 1710 & \\
\hline Rata-rata Nilai & $\mathbf{4 2 , 8}$ \\
\hline
\end{tabular}

Berdasarkan tabel diatas dapat dipihat bahwa data hasil ulangan harian siswa pra tindakan penelitian memiliki rata-rata 42,8 .

\section{Observasi I}

Observasi pelaksanaan pembelajaran siklus I dilakukan dengan meminta siswa untuk menyelesaikan soal-soal logika matematika yang diberikan sebanyak 10 butir soal kepada 40 orang siswa. Deskripsi hasil ulangan harian siswa pada siklus I terdapat pada tabel 2. Pelaksanaan pembelajaran pada siklus I ini diselenggarakan pada tanggal 3 Maret 2011.

Tabel 2. Hasil Ulangan Harian Siklus I

\begin{tabular}{cccc}
\hline No & Nilai & Frekuensi & Prosentase \\
\hline 1 & 60 & 19 & $47,5 \%$ \\
\hline 2 & 70 & 12 & $30 \%$ \\
\hline 3 & 80 & 2 & $5 \%$ \\
\hline 4 & 90 & 7 & $17,5 \%$ \\
\hline Jumlah & 40 & $100 \%$ \\
\hline Jumlah Total Nilai & 2770 & \\
\hline Rata-rata Nilai & $\mathbf{6 9 , 3}$ \\
\hline
\end{tabular}

Hasil analisis soal dari 10 butir pertanyaan yang digunakan untuk melihat kemampuan siswa dalam menjawab soalsoal logika matematika terdapat pada tabel 3 dibawah ini.

Tabel 3. Ringkasan Hasil Analisis Soal Ulangan Harian Siklus I

\begin{tabular}{|c|c|c|c|c|c|c|c|c|c|c|c|}
\hline Butir Soal & 1 & 2 & 3 & 4 & 5 & 6 & 7 & 8 & 9 & 10 & Total \\
\hline Jumlah Skor & 400 & 230 & 380 & 130 & 190 & 330 & 380 & 140 & 300 & 340 & 2770 \\
\hline Jumlah Skor Maksimal & 400 & 400 & 400 & 400 & 400 & 400 & 400 & 400 & 400 & 400 & 4000 \\
\hline Skor Rata-rata & 10 & 5,9 & 9,5 & 3,3 & 4,8 & 8,3 & 9,5 & 3,5 & 7,5 & 8,5 & 69,3 \\
\hline Nilai Ketuntasan & & & & & & & & & & & \\
\hline$<60$ & 0 & & \multirow{2}{*}{\multicolumn{9}{|c|}{$\begin{array}{l}\text { Jumlah siswa yang tuntas adalah } 40 \text { dari } 40 \text { siswa, hal ini } \\
\text { dapat diartikan bahwa banyak siswa yang tuntas adalah } \\
100 \%\end{array}$}} \\
\hline$\geq 60$ & 40 & & & & & & & & & & \\
\hline
\end{tabular}


4. Analisis dan Refleksi I

a. Ketuntasan Belajar

Banyak siswa seluruhnya 40 siswa, banyak siswa yang tuntas belajarnya 40 siswa dan prosentase banyaknya siswa yang tuntas $100 \%$.

b. Kesimpulan

1) Tidak perlu diadakan perbaikan karena siswa tuntas semua.

2) Perlu perbaikan pengajaran untuk soal no. 4, 5 dan 8

Dari analisa diatas dapat diambil kesimpulan bahwa pada kelas X-1 dikatakan Tuntas belajar minimal $85 \%$ dari jumlah siswa dalam kelas tersebut. Hal ini menunjukkan bahwa kegiatan pembelajaran telah berhasil dan dapat dilanjutkan ketahap pembelajaran berikutnya. Sedangkan dari soal yang diberikan, ternyata soal no. 4, 5, dan 8 perlu mendapatkan perbaikan karena dari skor yang tercapai ada $33 \%$ untuk soal no. $4,48 \%$ untuk soal no. 5 dan $35 \%$ untuk soal no. 8. Nilai rata-rata secara klasikal adalah 69,3. Ditinjau dari perolehan nilai hasil tes datanya dapat dilihat pada tabel 4 .

Tabel 4. Distribusi Frekuensi Data Perolehan Nilai Siswa pada Siklus I

\begin{tabular}{ccccc}
\hline Kelompok Nilai & Interval Nilai Siklus I & Frekuensi & Prosentase & Kualitas Nilai \\
\hline 1 & $0-59$ & 0 & $0 \%$ & Kurang \\
\hline 2 & $60-89$ & 33 & $83 \%$ & Cukup \\
\hline 3 & $90-100$ & 7 & $17 \%$ & Baik \\
\hline
\end{tabular}

Dari tabel 4 dapat dilihat bahwa siswa yang memperoleh nilai kurang tidak ada.
Hasil pengamatan pada siklus I tentang kinerja dapat dilihat pada tabel berikut:

Tabel 5. Ringkasan Hasil Pengamatan Kolaborator pada Siklus I

\begin{tabular}{|c|c|c|c|c|}
\hline \multirow{2}{*}{ No. } & \multirow{2}{*}{ Aspek yang diamati } & \multicolumn{3}{|c|}{ Penilaian dan Pengamatan } \\
\hline & & Kurang & Cukup & Baik \\
\hline \multirow[t]{4}{*}{1.} & Pendahuluan & & & \\
\hline & a. Memotivasi minat siswa & $\sqrt{ }$ & & \\
\hline & b. Menghubungkan dengan pelajaran yang lalu & $\sqrt{ }$ & & \\
\hline & c. Menyampaikan tujuan pembelajaran & & $\sqrt{ }$ & \\
\hline \multirow[t]{9}{*}{2.} & Kegiatan inti & & & \\
\hline & a. Memberikan masalah Problem Based Learning & & $\sqrt{ }$ & \\
\hline & $\begin{array}{l}\text { b. Mengarahkan siswa untuk menemukan jawaban dan cara } \\
\text { menjawab soal dengan memberi bantuan seperlunya }\end{array}$ & & $\sqrt{ }$ & \\
\hline & c. Mengamati cara siswa menyelesaikan masalah secara bergiliran & & $\sqrt{ }$ & \\
\hline & $\begin{array}{l}\text { d. Mengajak siswa membandingkan/ mendiskusikan jawaban } \\
\text { dengan jawaban temannya }\end{array}$ & & $\sqrt{ }$ & \\
\hline & $\begin{array}{l}\text { e. Mendorong siswa untuk mengemukakan pemikirannya atau } \\
\text { menanggapi pendapat temannya. }\end{array}$ & $\sqrt{ }$ & & \\
\hline & f. Menghargai berbagai pendapat & & $\sqrt{ }$ & \\
\hline & g. Mengarahkan siswa menarik kesimpulan & & $\sqrt{ }$ & \\
\hline & h. Memberi kesempatan pada siswa untuk bertanya/menjawab & $\sqrt{ }$ & & \\
\hline \multirow[t]{3}{*}{3.} & Penutup & & & \\
\hline & a. Menegaskan kembali kesimpulan materi & $\sqrt{ }$ & & \\
\hline & b. Memberi tugas pada siswa & $\sqrt{ }$ & & \\
\hline 4. & Pengelolaan Waktu & & $\sqrt{ }$ & \\
\hline 5. & Penampilan Guru & & & $\sqrt{ }$ \\
\hline \multirow[t]{4}{*}{6.} & Suasana Kelas & & & \\
\hline & a. Antusias siswa & & $\sqrt{ }$ & \\
\hline & b. Antusias guru & & & $\sqrt{ }$ \\
\hline & Jumlah & 6 & 9 & 2 \\
\hline
\end{tabular}


Berdasarkan hasil pelaksanaan dan pengamatan pada siklus I ditemukan kegagalan yaitu:

a. Dilihat dari perolehan nilai tes, siswa yang memperoleh nilai baik (90-100) adalah 7 orang (17\%), yang memperoleh nilai cukup (60-89) adalah 33 siswa (83\%), tetapi yang memperoleh nilai kurang (0-59) tidak ada $(0 \%)$.

b. Keterlaksanaan pembelajaran siklus I berjumlah 9 point pada kriteria cukup dari 17 aspek penilaian.

\section{Siklus II}

1. Perencanaan tindakan II

Pada siklus II peneliti lebih meningkatkan kegiatan pembelajaran dari apa yang telah dilakukan pada siklus I yaitu ingin meningkatkan kreativitas siswa kelas X-1 UPT SMA Negeri 2 Sumenep dalam pembelajaran Logika matematika agar lebih maksimal dan kreatif dalam pemahaman konsep dan penguasaan materi pembelajaran sehingga dilakukan dengan belajar kelompok. Adapun perencanaannya adalah sebagai berikut:

a) Peneliti diminta belajar kelompok untuk membahas penyelesaian soalsoal Kolaborator;

b) Peneliti memberikan tugas secara berkelompok dan individu; diberi kesempatan untuk menanyakan hal-hal yang belum jelas dan memberi bimbingan pada setiap kelompok yang mengamati kesulitan menyelesaikan soal Logika.

c) Peneliti memberikan bimbingan kepada setiap kelompok yang mengalami kesulitan menyelesaikan soal-soal, kemudian Kolaborator membuat catatan pribadi, dan memberi tes serta angket kepada siswa.
2. Pelaksanaan tindakan II

Siklus II dilaksanakan pada tanggal 11 Maret 2011 yang membahas tentang Logika matematika. Pelaksanaan pembelajaran yang diterapkan sama seperti siklus I tetapi dimodifikasi sedikit lebih menekankan pada kreativitas siswa dalam belajar. Peneliti membagi semua siswa dalam kelompok heterogen yang terdiri dari 4-5 orang setiap kelompok:

a) Tiap orang dalam masing-masing kelompok membuat soal-soal yang ada hubungannya dengan pokok bahasan seperti yang dicontohkan di papan tulis.

b) Membicarakan soal yang telah dibuat masing-masing orang dalam kelompok, kemudian hasilnya didiskusikan.

c) Masing-masing anggota kelompok mengerjakan soal berdasarkan pertanyaan hasil kesepakatan.lalu membandingkan jawaban antar anggota kelompok.

\section{Observasi II}

Peneliti meminta siswa untuk menyelesaikan soal-soal logika matematika yang diberikan. Ditinjau dari ketuntasan siswa, datanya dapat dilihat pada tabel 6 .

Tabel 6. Hasil Ulangan Harian Siklus II

\begin{tabular}{cccc}
\hline No & Nilai & Frekuensi & Prosentase \\
\hline 1 & 60 & 14 & $35 \%$ \\
\hline 2 & 70 & 13 & $32,5 \%$ \\
\hline 3 & 80 & 2 & $5 \%$ \\
\hline 4 & 90 & 4 & $10 \%$ \\
\hline 5 & 100 & 7 & $17,5 \%$ \\
\hline Jumlah & 40 & $100 \%$ \\
\hline Jumlah Total Nilai & 2970 & \\
\hline Rata-rata Nilai & $\mathbf{7 4 , 3}$ \\
\hline
\end{tabular}

Hasil analisis soal dari 10 butir pertanyaan yang digunakan untuk melihat kemampuan siswa dalam menjawab soalsoal logika matematika terdapat pada tabel 6 dibawah ini. 
Tabel 6. Ringkasan Hasil Analisis Soal Ulangan Harian Siklus II

\begin{tabular}{|c|c|c|c|c|c|c|c|c|c|c|c|}
\hline Data & 1 & 2 & 3 & 4 & 5 & 6 & 7 & 8 & 9 & 10 & Total \\
\hline Jumlah Skor & 400 & 230 & 380 & 130 & 190 & 330 & 380 & 140 & 300 & 340 & 2970 \\
\hline Jumlah Skor Maksimal & 400 & 400 & 400 & 400 & 400 & 400 & 400 & 400 & 400 & 400 & 4000 \\
\hline Skor Rata-rata & 10 & 8,3 & 9,8 & 6,3 & 6,3 & 9,5 & 8,8 & 4,3 & 6,0 & 6,5 & 74,3 \\
\hline \multicolumn{12}{|l|}{ Nilai Ketuntasan } \\
\hline$<60$ & \multicolumn{2}{|l|}{0} & \multirow{2}{*}{\multicolumn{9}{|c|}{$\begin{array}{l}\text { Jumlah siswa yang tuntas adalah } 40 \text { dari } 40 \text { siswa, hal ini } \\
\text { dapat diartikan bahwa banyak siswa yang tuntas adalah } \\
100 \%\end{array}$}} \\
\hline$\geq 60$ & \multicolumn{2}{|l|}{40} & & & & & & & & & \\
\hline
\end{tabular}

\section{Analisa dan Refleksi II}

Setelah melakukan pengamatan terhadap hasil observasi II kemampuan guru mengelola pembelajaran dan aktivitas siswa dalam pembelajaran Problem-Based Learning ternyata hasilnya sudah baik, hal itu tampak pada data hasil analisa kemampuan guru mengelolah pembelajaran ProblemBased Learning sehingga pembelajaran menjadi lebih aktif dan siswa kreatif untuk menyelesaikan soal-soal Logika matematika serta aktivitas siswa dalam pembelajaran tersebut sudah baik.

\section{Pembahasan Hasil Penelitian}

Dari hasil penelitian tindakan kelas selama siklus I sampai dengan siklus II dilakukan pengelompokan hasil-hasil nilai ulangan harian. Hal ini agar lebih mudah menganalisanya. Hasil analisa dari keseluruhan siklus adalah sebagai berikut:

Tabel 7. Data Hasil Belajar sebelum Diadakan Penelitian

\begin{tabular}{lccc}
\hline \multirow{2}{*}{ Uraian } & \multicolumn{3}{c}{ Penilaian } \\
\cline { 2 - 4 } & Pra PTK & Siklus I & Siklus II \\
\hline $\begin{array}{l}\text { Rata-rata } \\
\text { nilai ulangan } \\
\text { harian }\end{array}$ & 42,8 & 69,3 & 74,3 \\
\hline
\end{tabular}

\section{Hasil Analisa}

1. Kenaikan prosentase rata-rata Pra PTK dan siklus I.

$$
\mathrm{T}=\frac{42,8}{69,3} \times 100=61,76 \%
$$

2. Kenaikan prosentase siklus I dan siklus II

$$
\mathrm{T}=\frac{69,3}{74,3} \times 100=93,27 \%
$$

Meskipun dalam PTK ini dalam siklus I dan siklus II semua siswa tuntas semua, maka PTK tetap dilaksanakan pada siklus-siklus berikutnya karena untuk mengetahui sejauh mana kemampuan siswa dalam menerima materi pelajaran dan untuk mengetahui kesulitan apa yang dihadapi siswa dalam menerima materi pelajaran.

\section{PENUTUP}

\section{Simpulan}

Setelah peneliti cermati selama dalam kegiatan Penelitian Tindakan Kelas dari proses sampai hasil maka peneliti menyimpulkan sebagai berikut :

1) Dengan metode Problem Based Learning dapat meningkatkan kemampuan siswa dalam menyelesaikan soal logika Matematika di kelas X-I UPT SMA Negeri 2 Sumenep Tahun Pelajaran 20102011; Hal ini dapat dilihat dari perolehan nilai rata-rata ulangan harian yang semua sebelum diadakan penelitian 42,8 dengan ketuntasan $43 \%$ pada siklus I 69,3 dengan ketuntasan $69 \%$ dan pada siklus II 74,3 dengan ketuntasan $74 \%$.

2) Problem Based Learning pada pokok bahasan logika Matematika telah memberikan nuansa baru dalam pembelajaran Matematika sehingga 
pembelajaran lebih efektif. kreatif, aktif, dan menyenangkan.

\section{Saran-saran}

Berdasarkan hasil penelitian tindakan kelas dapat dikemukakan saransaran yang bermanfaat bagi peneliti selanjutnya, guru dan sekolah sebagai berikut:

1) Pembelajaran Matematika hendaknya bervariasi dan tidak monoton sehingga hasil pembelajaran dapat lebih maksimal dan selalu aktif dalam melibatkan siswa selama kegiatan pembelajaran berlangsung;

2) Seorang guru hendaknya terampil dan dapat menguasai berbagai metode pembelajaran agar siswa tidak bosan dan lebih mudah memahami materi pelajaran;

3) Hendaknya guru selalu memotivasi siswa agar belajar dulu dirumah tentang materi yang akan dibahas pada pertemuan berikutnya, supaya dalam pembelajaran siswa memiliki gambaran materi yang akan dibahas berikutnya.

\section{DAFTAR PUSTAKA}

Dini R. 2005. Pengantar Dasar Matematika. Diktat Program Studi Matematika STKIP PGRI Blitar.

Djuweni. 2005. Penelitian Tindakan Kelas. Makalah disajikan dalam acara peningkatan Profesionalisme Guru, Dikda Kota Blitar, SMP/SMA se Kota Blitar, Maret 2005.

Dimyati, Mudjiono. 1998. Belajar Pembelajaran. Jakarta: Asdi Mahasatya. Milyasa, E. 2004. Implementasi Kurikulum 2004 (Panduan Pembelajaran KBK). Bandung: Rosdakarya.

Nurhadi, Yasin BY, Senduk AG. 2004. Pembelajaran Kontekstual dan Penerapan dalam KBK. Malang: Universitas Negeri Malang.
PPGM. 1999. Pembelajaran Matematika Yang Aktif dan Efektif. Yogyakarta: Pusat Pengembangan Penataran Guru.

Riki Suliana. 2005. Dasar-dasar dan Proses Pembelajaran. Blitar Program Studi Matematika STKIP PGRI Blitar.

Suryabrata S, 1984. Psikologi Pendidikan. Yogyakarta: Rajawali Pers.

Suryabrata S, 2003. Metodologi Penelitian. Yogyakarta: Rajawali Pers.

Soesianto F, Dwijono D. 2003. Logika Proposisional. Yogyakarta: Andi.

Tim Penyusun Intan Pariwara, 2004. Matematika untuk SMA Jilid $1 b$. Klaten, Intan Pariwara (3-32).

Wirodikusumo, Sartono. 2004. Matematika untuk SMA Kelas X. Jakarta: Erlangga (123-189). , 2003. Kurikulum 2004. Standar Kompetensi Mata Pelajaran Matematika SMA dan $M A$. Jakarta: Depdiknas (15). 